\section{Kidney \\ Blood Pressure Research}

Kidney Blood Press Res 2017;42:257-266

DOI: $10.1159 / 000477422$

Published onlıne: IVIay 19, 2017

Accepted: February 21, 2017

This article is licensed under the Creative Commons Attibution This article is licensed under the Creative Commons Attribution-NonCommercial-NoDerivatives 4.0 International License (CC BY-NC-ND) (htl.//Www.karger.com/Services/OpenAccessLicense). Usage and distribution

\title{
Routine Monitoring of Sodium and Phosphorus Removal in Peritoneal Dialysis (PD) Patients Treated with Continuous Ambulatory PD (CAPD), Automated PD (APD) or Combined CAPD+APD
}

\author{
Veronika Moor ${ }^{a}$ Robert Wagner ${ }^{a, b, c} \quad$ Michael Sayer $^{a} \quad$ Marlies Petsch ${ }^{a}$ \\ Sandra Rueba, ${ }^{a, b}, c$ Hans-Ulrich Häring ${ }^{a, b, c}$ Nils Heyne ${ }^{a, b, c}$ Ferruh Artunc ${ }^{a, b, c}$ \\ aDepartment of Internal Medicine, Division of Endocrinology, Diabetology, Vascular Disease, \\ Nephrology and Clinical Chemistry, University Hospital Tübingen; 'Institute of Diabetes Research and \\ Metabolic Diseases (IDM) of the Helmholtz Center Munich at the University of Tübingen; 'German \\ Center for Diabetes Research (DZD), Tübingen, Germany
}

\section{Key Words}

APD $・$ CAPD +APD • CAPD • Phosphorus • Peritoneal dialysis • Sodium

\begin{abstract}
Background: Adequate removal of sodium $(\mathrm{Na})$ and phosphorus $(\mathrm{P})$ is of paramount importance for patients with dialysis-dependent kidney disease can easily quantified in peritoneal dialysis (PD) patients. Some studies suggest that automated PD (APD) results in lower $\mathrm{Na}$ and P removal. Methods. In this study we retrospectively analysed our data on $\mathrm{Na}$ and $\mathrm{P}$ removal in PD patients after implementation of a routine monitoring in 2011. Patients were stratified in those treated with continuous ambulatory PD (CAPD, $n=24)$, automated PD (APD, n=23) and APD with one bag change $(C A P D+A P D, n=10)$. Until 2015 we collected time-varying data on $\mathrm{Na}$ and $\mathrm{P}$ removal from each patient (median 5 [interquartile range 4-8] values). Results: Peritoneal $\mathrm{Na}$ and $\mathrm{P}$ removal (mmol per $24 \mathrm{~h} \pm$ standard deviation) was $102 \pm 48$ and $8 \pm 2$ in the CAPD, $90 \pm 46$ and $9 \pm 3$ in the APD and $126 \pm 39$ and $13 \pm 2$ in the CAPD+APD group (ANOVA $P=0.141$ and $<0.001$ ). Taking renal excretion into account total $\mathrm{Na}$ and $\mathrm{P}$ removal (mmol per 24h) was $221 \pm 65$ and $16 \pm 5$ in the CAPD, $189 \pm 58$ and $17 \pm 6$ in the APD and $183 \pm 38$ and $16 \pm 6$ in the CAPD+APD group ( $P=0.107$ and 0.764$)$. Over time, peritoneal removal of $\mathrm{Na}$ but not that of $\mathrm{P}$ increased in all groups. In patients with modifications of $\mathrm{PD}$ treatment, $\mathrm{Na}$ but not $\mathrm{P}$ removal was significantly increased over-time. Conclusions: Overall
\end{abstract}

V. Moor and R. Wagner contributed equally and therefore share first authorship. 


\section{Kidney Blood Pressure Research}

$\mathrm{Na}$ and $\mathrm{P}$ removal were similar with different PD modalities. Individualized adjustments of PD prescription including icodextrin use or higher glucose concentration can improve Na removal while P removal is mainly determined by the dialysate volume.

\section{Introduction}

Chronic kidney disease (CKD) leads to disturbance of whole-body sodium (Na) and phosphorus (P) balance and typically results in $\mathrm{Na}$ and $\mathrm{P}$ retention in advanced renal disease, particularly in those with dialysis-dependent end-stage renal disease (ESRD). Na and $\mathrm{P}$ retention are key elements in the pathogenesis of cardiac impairment and secondary hyperparathyroidism, both important predictors of mortality in ESRD patients [1-4]. Hence, adequate $\mathrm{Na}$ and $\mathrm{P}$ removal is of paramount importance for dialysis-dependent ESRD patients [5]. In contrast to hemodialysis patients, removal of $\mathrm{Na}$ and $\mathrm{P}$ can easily be quantified in peritoneal dialysis (PD) patients. A recent study suggested that PD results in higher P retention due to reduced clearance compared to HD [6]. This could be particularly true for patients treated with automated PD (APD) that has been reported to result in lower Na and P removal [7-9]. For Na, lower removal during APD can be explained by sodium sieving during the first hour of the dwell time due to transcellular water transport by aquaporins $[10,11]$. Net Na mass transfer takes place thereafter through small pores driven by chemical gradient and solvent drag. For P, transport across the peritoneum also involves small pores and is hindered by the intracellular distribution of $\mathrm{P}$ and the large radius of the hydrated phosphate ions [12]. Hence, adequate peritoneal $\mathrm{Na}$ and $\mathrm{P}$ removal is expected to be higher with an increasing dwell time and a higher $\mathrm{P}$ transporter status $[9,13]$.

Given these caveats, Na and P removal can still be influenced by the PD prescription such as adapting dialysate volume, glucose concentration, usage of icodextrin or number of exchanges [14]. As residual renal function deteriorates adequacy of $\mathrm{Na}$ and $\mathrm{P}$ removal by PD becomes even more important. Measuring $\mathrm{Na}$ and $\mathrm{P}$ removal $\mathrm{PD}$ helps to assess the efficacy of the current regimen and to adapt the PD prescription when there is evidence of $\mathrm{Na}$ and $\mathrm{P}$ retention, particularly in APD patients. It furthers helps to illustrate how much of $\mathrm{Na}$ and $\mathrm{P}$ the patient can orally ingest to maintain balance. For these reasons, we have implemented a routine monitoring of $\mathrm{Na}$ and $\mathrm{P}$ removal in our center that is measured in addition to measurement of Kt/V and weekly creatinine clearance. Here we report on the results of this monitoring during a 4-year time span (2011-2015) with emphasis on the PD modality and time trends.

\section{Materials and Methods}

\section{Study design and subjects}

All incident and prevalent PD patients treated in our department since implementation of routine monitoring of $\mathrm{Na}$ and $\mathrm{P}$ removal in October 2011 were enrolled in the study. This routine monitoring was done at the outpatient visits of each patient every 3 months in addition to measurement of Kt/V and weekly creatinine clearance from the effluent and urine that had been collected on the previous day. Na and $\mathrm{P}$ removal were calculated from the measured $\mathrm{Na}$ (using ion-selective electrodes) and $\mathrm{P}$ concentrations and the effluent and urine volumes. For $\mathrm{Na}$, values had to be corrected for the $\mathrm{Na}$ content of the dialysate volume. GFR was taken as the average of creatinine and urea clearance that were calculated from the $24 \mathrm{~h}$ urine. Measurements of the urine and effluent $\mathrm{Na}$ and $\mathrm{P}$ concentration were done on the same day of the outpatient visit and then transferred to the dialysis software Nephro 7 (Medvision, Bad Soest, Germany) that was programmed to compute the peritoneal and renal $\mathrm{Na}$ and $\mathrm{P}$ removal. Data for this retrospective study were extracted from the electronic file until September $1^{\text {st }} 2015$. 


\section{Kidney Blood Pressure Research}

51 patients were stratified in those treated with CAPD, APD and combined CAPD+APD. 6 patients who changed PD modality were analysed per modality resulting in group sizes of 24 patients in the CAPD, 23 patients in the APD and 10 patients in the CAPD+APD group. Patients were treated with glucose $1.36 \%$ and/or 2.27 and/or $3.86 \%$ (only double-chamber bags), amino acids $1.1 \%$ and icodextrin $7.5 \%$ as clinically needed. CAPD was performed with 3 to 4 manual bag changes per day. APD was done with a cycler (Baxter, Deerfield, Illinois, USA) over 7.5-9 hours with 4-6 cycles, $75-85 \%$ tidal volume and a last fill of $1.5-2$
Table 1. Patient characteristics. Arithmetic means \pm SD. P derived from ANOVA

\begin{tabular}{|c|c|c|c|c|}
\hline & $\begin{array}{l}\text { CAPD } \\
(\mathrm{n}=24)\end{array}$ & $\begin{array}{c}\text { APD } \\
(n=23)\end{array}$ & $\begin{array}{c}\text { CAPD+APD } \\
(\mathrm{n}=10)\end{array}$ & $P$ \\
\hline renal diseases & & & & \\
\hline $\begin{array}{l}\text { - diabetic/hypertensive } \\
\text { nephropathy }\end{array}$ & 9 & 5 & 5 & n.a. \\
\hline - glomerulonephritis & 5 & 7 & 3 & \\
\hline - polycystic kidney disease & 2 & 3 & 2 & \\
\hline - obstructive & 0 & 2 & 0 & \\
\hline - toxic & 5 & 4 & 0 & \\
\hline - cardiorenal & 3 & 1 & 0 & \\
\hline - unknown/other & 0 & 1 & 0 & \\
\hline gender ratio $+: 0^{x}$ & $14: 10$ & $6: 17$ & $3: 7$ & 0.061 \\
\hline age at study inclusion & $52 \pm 15$ & $54 \pm 16$ & $57 \pm 19$ & 0.715 \\
\hline time on PD, years & $2.7 \pm 2.2$ & $2.4 \pm 1.8$ & $4.7 \pm 2.4$ & 0.014 \\
\hline time in study, years & $1.8 \pm 1.0$ & $1.6 \pm 0.9$ & $3.0 \pm 1.5$ & 0.005 \\
\hline $\begin{array}{l}\text { GFR } \\
\left(\mathrm{mL} / \mathrm{min} / 1.73 \mathrm{~m}^{2}\right)\end{array}$ & $4.7 \pm 2.7$ & $4.0 \pm 3.3$ & $1.1 \pm 1.1$ & 0.005 \\
\hline $\begin{array}{l}\text { dialysate volume, } \\
\text { L per pro } 24 \mathrm{~h}\end{array}$ & $5.8 \pm 1.8$ & $10.4 \pm 2.0$ & $12.6 \pm 2.1$ & $<0.001$ \\
\hline glucose concentration, $\%$ & $1.73 \pm 0.34$ & $2.01 \pm 0.43$ & $2.12 \pm 0.39$ & 0.014 \\
\hline patients with icodextrin & $12 / 24$ & $19 / 23$ & $10 / 10$ & 0.003 \\
\hline $\mathrm{D} / \mathrm{P}$ creatinine & $0.76 \pm 0.15$ & $0.82 \pm 0.09$ & $0.71 \pm 0.11$ & 0.095 \\
\hline $\begin{array}{l}\text { ultrafiltration during PET- } \\
\text { test, } \mathrm{mL} / 4 \mathrm{~h}\end{array}$ & $441 \pm 268$ & $341 \pm 277$ & $420 \pm 286$ & 0.514 \\
\hline total $\mathrm{Kt} / \mathrm{V}$ & $2.25 \pm 0.43$ & $2.38 \pm 0.69$ & $1.91 \pm 0.16$ & 0.066 \\
\hline $\begin{array}{l}\text { total creatinine clearance, } \\
\mathrm{L} / \text { week } / 1.73 \mathrm{~m}^{2}\end{array}$ & $115 \pm 48$ & $97 \pm 41$ & $57 \pm 17$ & 0.002 \\
\hline peritonitis episodes & 4 & 8 & 4 & n.a. \\
\hline $\begin{array}{l}\text { peritonitis rate (patient } \\
\text { months per episode) }\end{array}$ & 259 & 125 & 114 & n.a. \\
\hline hemoglobin, g/dl & $10.1 \pm 1.2$ & $10.5 \pm 1.0$ & $10.2 \pm 0.5$ & 0.527 \\
\hline albumin, g/dl & $3.7 \pm 0.5$ & $3.8 \pm 0.5$ & $3.8 \pm 0.7$ & 0.853 \\
\hline C-reactive protein, $\mathrm{mg} / \mathrm{dl}$ & $3.3 \pm 2.9$ & $3.4 \pm 3.3$ & $5.0 \pm 4.7$ & 0.424 \\
\hline
\end{tabular}

L during daytime. CAPD+APD was similarly performed as usual APD except for an additional 3-5 hours daytime fill with $2 \mathrm{~L}$ at $6 \mathrm{pm}$ until begin of overnight APD. The decision about treatment modality CAPD vs. APD primarily related to the patient's preference and secondly to transporter status. High transporters with low ultrafiltration were treated with APD. CAPD+APD was commenced when residual renal function strongly declined and adequacy goals were not achieved. Volume status was measured with the bioimpedance spectroscopy (BCM monitor, Fresenius Medical Care Homburg, Germany). Blood pressure data were derived from self-measurements with a uniform oscillometric device provided by Baxter (Deerfield, Illinois, USA). The study was approved the local ethics committee.

\section{Statistical analysis}

Each studied parameter was arithmetically averaged per patient over the whole study period and this average value was used in final analyses. The median number of replicates per patient was 5 (interquartile range 4-8) values during a median study period of $1.4(1.1 ; 2.6)$ years per patient. Differences between the groups were analysed with one-way analysis of variance (ANOVA) with Tukey-Kramer post-test. To account for differences in patient characteristics (table 1), groups were additionally compared with oneway analysis of covariance (ANCOVA) with adjustments made for time on PD, glucose concentration, usage of icodextrin (yes or no), dialysate volume and residual GFR. To analyse the time trend of the parameters, all single replicate values of a patient were entered by treatment group into a mixed model with time as fixed effects and patient identifier as random effects. To test group-specific differences in the time trend, the mixed model was repeated with group as an interaction term. Variables entering multivariable linear regression were selected from stepwise approach (enter when $p<0.2$, remove when $p>0.21$ ). Statistical analyses were done with MedCalc Statistical Software version 16.4.2 (MedCalc Software bvba, Ostend, Belgium) and JMP 11 (SAS Institute Inc., Cary, NC, USA). 


\section{Kidney Blood Pressure Research}

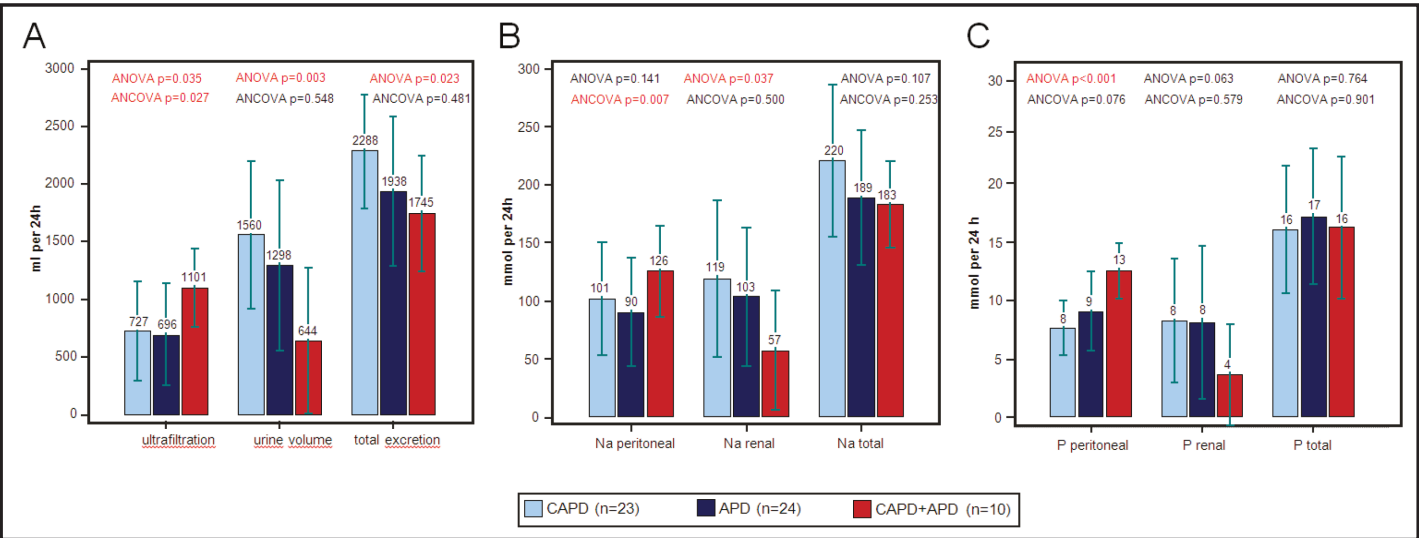

Fig. 1. Removal of fluid (A) by ultrafiltration and residual diuresis as well as peritoneal and renal removal of $\mathrm{Na}(\mathrm{B})$ and $\mathrm{P}(\mathrm{C})$. Total removal is derived from the sum of peritoneal and renal excretion. Arithmetic means with SD.

\section{Results}

Table 1 shows the characteristics of the groups that significantly differed with respect to time on $\mathrm{PD}$, average glucose concentration, usage of icodextrin, dialysate volume and residual GFR. Patients with CAPD+APD were longer on PD, had lower residual GFR, highest dialysate volume and glucose concentration as well as icodextrin usage. Transporter status was not different across the groups. Total $\mathrm{Kt} / \mathrm{V}$ and weekly creatinine clearance were highest among CAPD patients followed by APD patients. CAPD+APD patients had the lowest clearance values, particularly weekly creatinine clearance (table 1).

As shown in Fig. 1A, CAPD+APD patients had the highest ultrafiltration and inversely the lowest urine volume. CAPD patients had the lowest ultrafiltration, yet the highest urine volume resulting in the highest total fluid excretion. Peritoneal, renal and total Na removal is shown Fig 1B. Peritoneal Na removal was slightly lower in the APD group reaching statistical significance after adjusting for group differences with ANCOVA. In the CAPD+APD group, peritoneal Na removal was highest while renal $\mathrm{Na}$ excretion was the lowest. Total $\mathrm{Na}$ removal was similar across all groups with a tendency to highest values in the CAPD group. Peritoneal, renal and total P removal is shown Fig 1C. Peritoneal P removal was significantly higher and renal P excretion lower in the CAPD+APD group compared to the other groups. Total P excretion was similar across the groups.

Table 2 shows the time- and group-dependent changes in peritoneal and renal clearance as analysed with a mixed linear regression model. GFR was lost in the CAPD and APD groups with a similar rate, in the CAPD+APD the value was somewhat lower which may be explained with a very low baseline GFR. Similarly, urine volume fell in all groups by 236-266 $\mathrm{ml}$ per year. Inversely, dialysate volume increased in all groups, particularly in the APD and CAPD+APD group. As a result, ultrafiltration also increased with time which was, however, less pronounced in the APD group. While renal Na removal decreased, peritoneal Na removal increased with time and a tendency towards group-specific differences. Interestingly, peritoneal P removal remained stable throughout the study period, while renal P excretion decreased in all groups with time.

During the study period PD treatment was modified in 6 (12\%) patients who changed PD modality, mainly from CAPD to APD, and in 33 (58\%) patients whose PD treatment was changed (table 3 ). The median number of treatment changes were on average two per patient and similar across the groups (table $3, p=0.22$ ). During the first regimen, patients with and without treatment changes had a similar glucose concentration $(1.74[1.36 ; 1.97]$ vs. $1.82 \%$ [1.59; 2.10], $\mathrm{p}=0.31)$ and dialysate volume $(7.76[4.5 ; 10.0]$ vs. $7.91 \mathrm{~L}[5.0 ; 10.0]$, 


\section{Kidney Blood Pressure Research}

Table 2. Time dependence of studied parameters, Results of a mixed model with time as independent variable and group as an interaction term. Slope values of individual patients were averaged to give a quantitative estimate of the change with time

\begin{tabular}{|c|c|c|c|c|c|c|}
\hline parameter & group & $\begin{array}{c}\text { median slope } \\
\text { per year }\end{array}$ & $\mathrm{N}$ & $\mathrm{R}^{2}$ & $\begin{array}{c}\text { P for } \\
\text { change } \\
\text { with time }\end{array}$ & $\begin{array}{c}\text { P for } \\
\text { difference } \\
\text { between } \\
\text { groups }\end{array}$ \\
\hline \multirow{3}{*}{$\begin{array}{l}\mathrm{GFR}, \\
\mathrm{mL} / \mathrm{min} / 1.73 \mathrm{~m}^{2}\end{array}$} & CAPD & $-0.8(-2.3 ;-0.3)$ & 135 & 0.94 & $<0.0001$ & \multirow{3}{*}{0.0437} \\
\hline & APD & $-1.3(-2.5 ;-0.1)$ & 147 & 0.93 & $<0.0001$ & \\
\hline & $\mathrm{CAPD}+\mathrm{APD}$ & $-0.5(-0.8 ;-0.2)$ & 92 & 0.92 & $<0.0001$ & \\
\hline \multirow{3}{*}{$\begin{array}{l}\text { dialysate volume, } \\
\mathrm{mL} / 24 \mathrm{~h}\end{array}$} & CAPD & $+0(-79 ; 433)$ & 137 & 0.92 & $<0.0001$ & \multirow{3}{*}{$<0.0001$} \\
\hline & APD & +1049 (81; 3394) & 138 & 0.81 & $<0.0001$ & \\
\hline & CAPD +APD & $+606(41 ; 1239)$ & 123 & 0.81 & $<0.0001$ & \\
\hline \multirow{3}{*}{$\begin{array}{l}\text { urine volume, } \\
\mathrm{mL} / 24 \mathrm{~h}\end{array}$} & CAPD & $-253(-479 ; 94)$ & 146 & 0.81 & $<0.0001$ & \multirow{3}{*}{$<0.0001$} \\
\hline & APD & $-266(-691 ;-159)$ & 153 & 0.82 & $<0.0001$ & \\
\hline & CAPD +APD & $-236(-401 ;-153)$ & 95 & 0.86 & $<0.0001$ & \\
\hline \multirow{3}{*}{$\begin{array}{l}\text { ultrafiltration, } \\
\mathrm{mL} / 24 \mathrm{~h}\end{array}$} & CAPD & $+162(-133 ; 332)$ & 136 & 0.67 & 0.0156 & \multirow{3}{*}{0.0043} \\
\hline & APD & $+74(-362 ; 428)$ & 138 & 0.63 & 0.1693 & \\
\hline & CAPD+APD & $+284(124 ; 489)$ & 124 & 0.61 & $<0.0001$ & \\
\hline \multirow{3}{*}{$\begin{array}{l}\text { peritoneal } \mathrm{Na} \\
\text { elimination, } \mathrm{mmol} / 24 \mathrm{~h}\end{array}$} & CAPD & $+8(-24 ; 46)$ & 135 & 0.67 & 0.0150 & \multirow{3}{*}{0.0521} \\
\hline & APD & $+12(-41 ; 50)$ & 137 & 0.52 & 0.4584 & \\
\hline & $\mathrm{CAPD}+\mathrm{APD}$ & $+16(-14 ; 40)$ & 123 & 0.32 & 0.0032 & \\
\hline \multirow{3}{*}{$\begin{array}{l}\text { renal Na elimination, } \\
\mathrm{mmol} / 24 \mathrm{~h}\end{array}$} & CAPD & $-27(-54 ;-7)$ & 137 & 0.78 & 0.0003 & \multirow{3}{*}{$<0.0001$} \\
\hline & APD & $-27(-45,5)$ & 146 & 0.81 & $<0.0001$ & \\
\hline & CAPD+APD & $-27(-43 ;-11)$ & 89 & 0.81 & $<0.0001$ & \\
\hline \multirow{3}{*}{$\begin{array}{l}\text { peritoneal P elimination, } \\
\mathrm{mmol} / 24 \mathrm{~h}\end{array}$} & CAPD & $+1.1(0.3 ; 2.9)$ & 135 & 0.78 & 0.1230 & \multirow{3}{*}{0.5377} \\
\hline & APD & $+1.3(-0.5 ; 2.6)$ & 135 & 0.64 & 0.1782 & \\
\hline & CAPD +APD & $+0.2(-1.1 ; 1.5)$ & 122 & 0.21 & 0.4580 & \\
\hline \multirow{3}{*}{$\begin{array}{l}\text { renal P elimination, } \\
\mathrm{mmol} / 24 \mathrm{~h}\end{array}$} & CAPD & $-1.0(-2.8 ; 0)$ & 135 & 0.85 & 0.0496 & \multirow{3}{*}{0.0787} \\
\hline & APD & $-2.4(-5.2 ; 0.1)$ & 142 & 0.86 & $<0.0001$ & \\
\hline & $\mathrm{CAPD}+\mathrm{APD}$ & $-1.5(-2.6 ; 0.6)$ & 87 & 0.82 & $<0.0001$ & \\
\hline \multirow{3}{*}{ total Kt/V } & CAPD & $-0.05(-0.23 ; 0.08)$ & 138 & 0.83 & $<0.0001$ & \multirow{3}{*}{0.9813} \\
\hline & APD & $-0.23(-0.51 ; 0.25)$ & 142 & 0.78 & $<0.0001$ & \\
\hline & CAPD +APD & $-0.01(-0.08 ; 0.07)$ & 100 & 0.20 & 0.2404 & \\
\hline \multirow{3}{*}{$\begin{array}{l}\text { total creatinine clearance, } \\
\mathrm{L} / \text { week } / 1.73 \mathrm{~m}^{2}\end{array}$} & CAPD & $-10(-15 ;-1)$ & 139 & 0.89 & $<0.0001$ & \multirow{3}{*}{0.1824} \\
\hline & APD & $-15(-37 ; 8)$ & 142 & 0.86 & $<0.0001$ & \\
\hline & $\mathrm{CAPD}+\mathrm{APD}$ & $-7(-9 ;-2)$ & 100 & 0.90 & $<0.0001$ & \\
\hline
\end{tabular}

$\mathrm{p}=0.74)$. In patients with treatment changes, glucose concentration and dialysate volume were significantly increased to $2.04 \%([1.36 ; 2.27], \mathrm{p}=0.008)$ and $8.7 \mathrm{~L}([4.5 ; 10.0], \mathrm{p}=0.03)$. To analyse if the treatment changes resulted in increased solute removal we reanalysed the time-dependent data after stratification of patients with or without treatment changes. As shown in table 4, patients with treatment changes had significantly higher time-dependent changes in dialysate volume, ultrafiltration and peritoneal Na but not $\mathrm{P}$ removal compared to patients without treatment changes (table 4). Time-dependent changes of peritoneal Kt/V and creatinine clearance were not significantly different between the groups, although they tended to increase in the patients with treatment changes.

We also assessed the surrogates for $\mathrm{Na}$ and P retention such as increased blood pressure, overhydration, hyperphosphatemia and secondary hyperparathyroidism. As shown in Fig. $2 \mathrm{~A}$, systolic and diastolic blood pressure was not different between groups although patients with APD and CAPD+APD tended to have higher systolic and diastolic blood pressure. Overhydration as surrogate of Na retention was common in all groups and was highest in the CAPD group (Fig. 2B). Inversion of extracellular to intracellular water (E/I) was uniformly found across all groups. The number of antihypertensives including diuretics was 3-5 drug classes per patient with a great variability and no significant difference (Fig.2C).

Patients in the CAPD+APD group had the highest plasma phosphorus concentration (Fig. $3 \mathrm{~A}$ ) while plasma calcium values were very similar in all groups $(2.2-2.3 \mathrm{mM}, \mathrm{P}=0.108$; data not shown). Parathyroid hormone concentration was similar across all groups (Fig. 


\section{Kidney Blood Pressure Research}

Kidney Blood Press Res 2017;42:257-266

\begin{tabular}{l|l}
\hline $\begin{array}{l}\text { DOI: 10.1159/000477422 } \\
\text { Published onlIne: May 19, } 2017\end{array}$ & $\begin{array}{l}\text { (C) } 2017 \text { The Author(s). Published by S. Karger AG, Basel } \\
\text { www.karger.com/kbr }\end{array}$ \\
\hline
\end{tabular}

Moor/Wagner/Sayer et al.: Na and P Removal During PD
3A). CAPD+APD patients took the highest number of pills to bind phosphorus (Fig. 3B). However, the great variability precluded significant differences. Native and active vitamin D usage was identical in all groups (10 000 IE native vitamin D per week and $0.23 \mu$ g per day, $\mathrm{P}=0.728$ and 0.667 ).

Table 5 shows the results of a multivariate linear regression analysis to identify independent predictors of peritoneal $\mathrm{Na}$ and $\mathrm{P}$ removal. For $\mathrm{Na}$, glucose concentration and usage of icodextrin were independent predictors, while for $\mathrm{P}$ dialysate volume and plasma phosphate concentrations were independent predictors.

\section{Discussion}

This study shows that different PD modalities can achieve fairly high and comparable removal of $80-120 \mathrm{mmol} \mathrm{Na}$ and $8-12 \mathrm{mmol} \mathrm{P}$ through the

Table 4. Time dependence of peritoneal solute elimination according to treatment changes . Results of a mixed model with time as independent variable stratified according to treatment changes (yes/no). Treatment modality was not entered into the model. Slope values of individual patients were averaged to give a quantitative estimate of the change with time
Table 3. Course of PD treatment during study period

\begin{tabular}{|c|c|}
\hline study completed on single & 17 \\
\hline \multicolumn{2}{|l|}{ PD modality } \\
\hline terminated PD & 25 \\
\hline death & 13 \\
\hline transplanted & 6 \\
\hline switched to HD & 4 \\
\hline recovered renal function & 2 \\
\hline changed dialysis provider & 4 \\
\hline \multicolumn{2}{|l|}{ /lost to follow-up } \\
\hline changed PD modality & 6 \\
\hline CAPD to APD & 4 \\
\hline APD to CAPD & 1 \\
\hline $\mathrm{APD}$ to $\mathrm{APD}+\mathrm{CAPD}$ & 1 \\
\hline $\begin{array}{l}\text { median number of } \\
\text { treatment changes per } \\
\text { patient }\end{array}$ & 2 \\
\hline CAPD & 2 \\
\hline APD & 2 \\
\hline CAPD+APD & 3 \\
\hline \multicolumn{2}{|l|}{ patients without } \\
\hline treatment changes & $24^{*}$ \\
\hline CAPD & $11^{* *}$ \\
\hline APD & $11^{* * *}$ \\
\hline $\mathrm{CAPD}+\mathrm{APD}$ & $2 * * * *$ \\
\hline \multicolumn{2}{|c|}{$\begin{array}{l}*(42 \% \text { of all patients }) ; * *(42 \% \text { of all } \\
\text { CAPD patients }) ; * * *(43 \% \text { of all APD } \\
\text { patients }) ; * * *(20 \% \text { of all CAPD }+ \text { APD } \\
\text { patients })\end{array}$} \\
\hline
\end{tabular}

\begin{tabular}{|c|c|c|c|c|c|c|}
\hline parameter & group & $\begin{array}{c}\text { median slope per } \\
\text { year }\end{array}$ & $\mathrm{N}$ & $\mathrm{R}^{2}$ & $\begin{array}{l}\text { P for } \\
\text { change } \\
\text { with } \\
\text { time }\end{array}$ & $\begin{array}{c}\text { P for } \\
\text { differenc } \\
\mathrm{e} \\
\text { between } \\
\text { groups }\end{array}$ \\
\hline \multirow{2}{*}{$\begin{array}{l}\text { dialysate volume, } \\
\mathrm{mL} / 24 \mathrm{~h}\end{array}$} & \multirow{2}{*}{$\begin{array}{c}\text { no } \\
\text { changes } \\
\text { changes }\end{array}$} & $+383(-466 ; 942)$ & 126 & 0.76 & 0.0965 & \multirow{2}{*}{0.0034} \\
\hline & & $+1113(0 ; 1376)$ & 272 & 0.85 & $<0.0001$ & \\
\hline \multirow{2}{*}{$\begin{array}{l}\text { ultrafiltration, } \\
\mathrm{mL} / 24 \mathrm{~h}\end{array}$} & \multirow{2}{*}{$\begin{array}{c}\text { no } \\
\text { changes } \\
\text { changes }\end{array}$} & $-79(-464 ; 358)$ & 126 & 0.66 & 0.7027 & \multirow{2}{*}{$<0.0001$} \\
\hline & & $+259(-16 ; 429)$ & 272 & 0.60 & $<0.0001$ & \\
\hline \multirow{4}{*}{$\begin{array}{l}\text { peritoneal } \mathrm{Na} \\
\text { elimination, } \\
\text { mmol / } 24 \mathrm{~h} \\
\text { peritoneal } \mathrm{P} \\
\text { elimination, } \\
\text { mmol / } 24 \mathrm{~h}\end{array}$} & \multirow{2}{*}{$\begin{array}{l}\text { no } \\
\text { changes } \\
\text { changes }\end{array}$} & $-15(-61 ; 27)$ & 125 & 0.47 & 0.4607 & \multirow{2}{*}{0.0001} \\
\hline & & $13(-8 ; 46)$ & 270 & 0.50 & 0.0254 & \\
\hline & \multirow{2}{*}{$\begin{array}{c}\text { no } \\
\text { changes } \\
\text { changes }\end{array}$} & $+3(0 ; 4)$ & 124 & 0.44 & 0.8946 & \multirow[t]{2}{*}{0.5500} \\
\hline & & $+2(0 ; 3)$ & 268 & 0.58 & 0.0726 & \\
\hline \multirow[t]{2}{*}{ peritoneal Kt/V } & \multirow{2}{*}{$\begin{array}{c}\text { no } \\
\text { changes } \\
\text { changes }\end{array}$} & $-0.07(-0.22 ; 0.11)$ & 143 & 0.82 & 0.0035 & \multirow[t]{2}{*}{0.3240} \\
\hline & & $+0.19(0.00 ; 0.27)$ & 280 & 0.71 & $<0.0001$ & \\
\hline \multirow{2}{*}{$\begin{array}{l}\text { peritoneal } \\
\text { creatinine } \\
\text { clearance, } \\
\text { L/week } / 1.73 \mathrm{~m}^{2}\end{array}$} & \multirow{2}{*}{$\begin{array}{c}\text { no } \\
\text { changes } \\
\text { changes }\end{array}$} & $-1(-2 ; 0)$ & 128 & 0.86 & 0.1070 & \multirow[t]{2}{*}{0.3510} \\
\hline & & $-1(-2 ; 1)$ & 295 & 0.58 & 0.0225 & \\
\hline
\end{tabular}




\section{Kidney Blood Pressure Research}
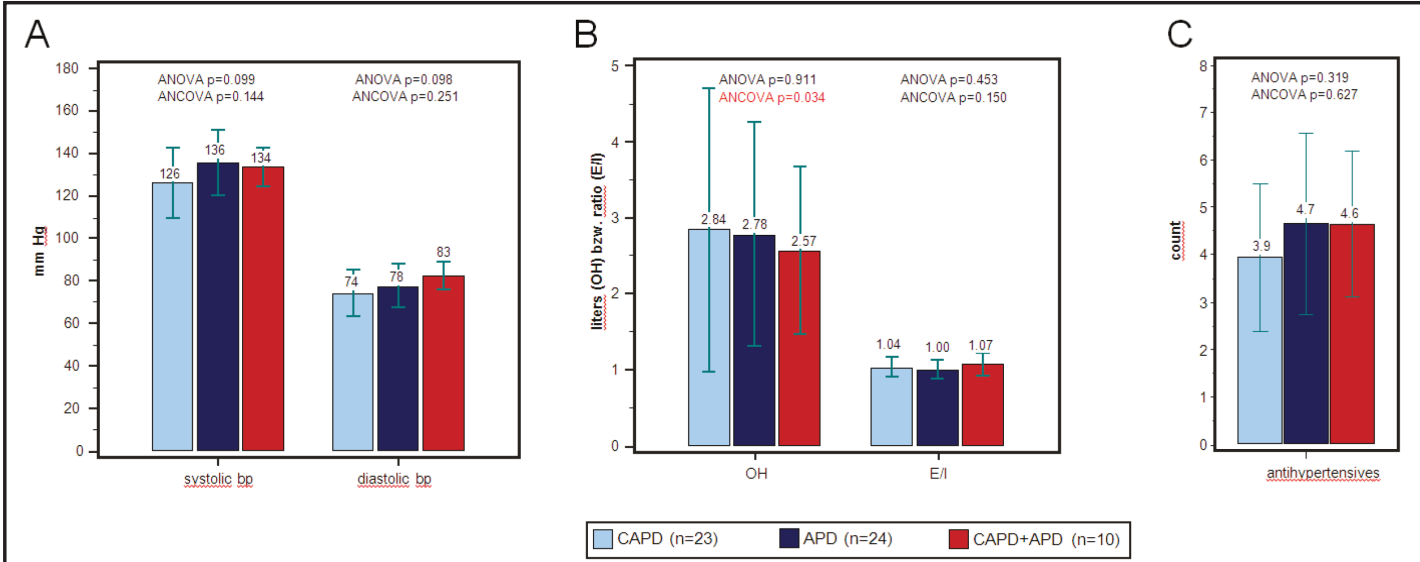

Fig. 2. Surrogates for Na retention and use of antihypertensive drugs, A Systolic and diastolic blood pressure, B Overhydration and ratio of extra- to intracellular water (E/I) from bioimpedance spectroscopy, C Number of classes of antihypertensive drug including diuretics (torasemid and xipamide counted separately). Arithmetic means with SD

peritoneum per day. Peritoneal $\mathrm{Na}$ removal was slightly higher in CAPD than in APD, while there CAPD tended to have lower peritoneal $P$ removal compared to APD. The combination of CAPD +APD achieved the highest values for both peritoneal $\mathrm{Na}$ and $\mathrm{P}$ removal compensating for the low residual renal function in these patients. Overall total $\mathrm{Na}$ and $\mathrm{P}$ removal were similar in the groups (180-220 mmol $\mathrm{Na}$ and 14$16 \mathrm{mmol} P$ per day). The superiority of the peritoneal removal rates achieved with CAPD+APD is not a new finding and was characterized by Blake et al. in 1996 [15]. In that study, CAPD+APD with a mid-day change lead to higher clearance rate

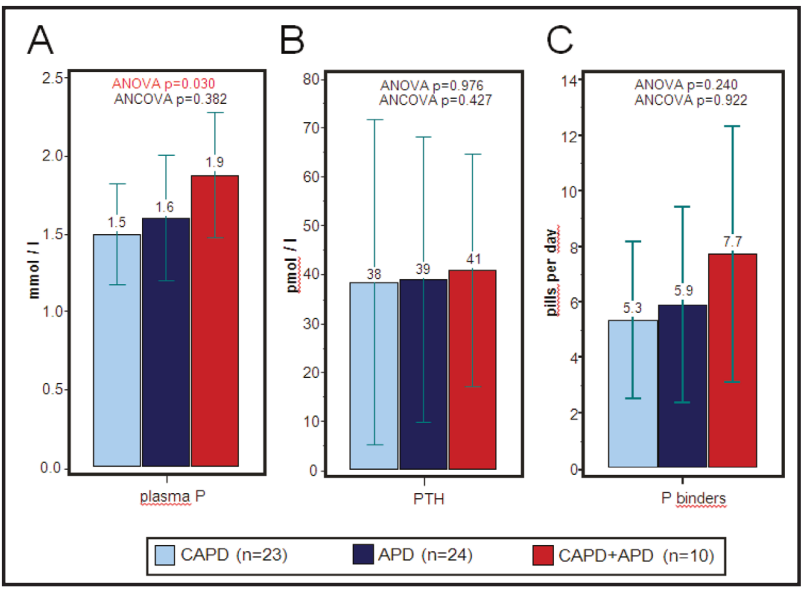

Fig. 3. Surrogates for $\mathrm{P}$ retention and use of phosphorus binders, Hyperphosphatemia (A), secondary hyperparathyroidism (B) and number of pills to bind phosphorus (C) including lanthan, calcium-containing, sevelamer and aluminium. Arithmetic means with SD

Table 5. Determinants of peritoneal Na and P removal as analysed by multivariable regression. All patients irrespective of the group were entered into the same model. SE standard error

\begin{tabular}{|c|c|c|c|c|}
\hline $\begin{array}{l}\text { independent } \\
\text { variable }\end{array}$ & model str & covariate & $\begin{array}{l}\text { coefficient } \\
\text { with SE }\end{array}$ & p-value \\
\hline$\overline{\text { peritoneal }}$ & adjusted $r^{2}=0.25$ & $y$-intercept & -22 & . \\
\hline \multirow{3}{*}{ Na removal } & $P=0.0004$ & gender ( $1=$ male, $2=$ female $)$ & $24 \pm 12$ & 0.0563 \\
\hline & & glucose con & $31 \pm 15$ & 0.0497 \\
\hline & & icodext & $43 \pm 14$ & 0.0051 \\
\hline peritoneal $\mathrm{P}$ & adjusted $r^{2}=0.59$ & $y$-intercept & -1.70 & - \\
\hline \multirow[t]{4}{*}{ removal } & $\mathrm{P}<0.0001$ & glucose concentration, \% & $1.37 \pm 0.85$ & 0.1148 \\
\hline & & icodextı & $1.30 \pm 0.81$ & 0.1177 \\
\hline & & dialysate & $0.36 \pm 0.11$ & 0.0030 \\
\hline & & plasma phosphate, $\mathrm{mM}$ & $2.55 \pm 0.80$ & 0.0024 \\
\hline
\end{tabular}




\section{Kidney Blood Pressure Research}

Kidney Blood Press Res 2017;42:257-266

\begin{tabular}{l|l}
\hline DOI: $10.1159 / 000477422$ & (C) 2017 The Author(s). Published by S. Karger AG, Basel
\end{tabular}

\begin{tabular}{l|l} 
Published online: May 19, $2017 \quad$ www.karger.com/kbr \\
\hline
\end{tabular}

Moor/Wagner/Sayer et al.: Na and P Removal During PD

across all transporter types compared to APD with or without daytime filling which can be explained with the time-dependence of $\mathrm{Na}$ and $\mathrm{P}$ removal. In our center we commence this intensive treatment when residual function is strongly reduced in an APD patient, such as after several years on PD. Instead of a mid-day exchange we prescribe a 3-5 hours dwell time at the evening which is well feasible in patients after returning from their work. Our data show that this approach ensures high peritoneal removal rates compensating for reduced renal excretion that occurred in all groups over time. With combined CAPD+APD adequate PD can be re-accomplished in an APD patient enabling to continue PD and to benefit from the advantages of this home dialysis method.

Our study shows that treatment changes had an impact on peritoneal solute removal over time (table 4). These were most pronounced for ultrafiltration and Na elimination and to a lesser extent in peritoneal urea or creatinine elimination suggesting that routine $\mathrm{Na}$ monitoring helped to guide treatment and ensure adequate sodium balance. Treatment changes encompassed increased dialysate volume, higher glucose concentration and use of icodextrin. In patients with APD, cycler settings were optimized on an individual basis e.g. taking into account transporter status. Some patients were transferred to APD or CAPD+APD. Our data confirm that using icodextrin is of particularly great importance for peritoneal $\mathrm{Na}$ and to a lesser extent for P removal [10]. In APD patients and in those with reduced residual renal function icodextrin seems to be essential. Increasing glucose concentration could also work as it was also a determinant of higher peritoneal $\mathrm{Na}$ and to a lesser extent $P$ removal. However, this will be limited by side effects of high glucose such as exacerbated hyperglycemia in diabetic patients, glucose overfeeding or peritoneal injury. In addition, high dialysate volume was found to be associated with damage to erythrocytes and eryptosis [16]. Interestingly, dialysate volume was an independent predictor only for $\mathrm{P}$ but not for $\mathrm{Na}$ removal. For P, plasma phosphorus concentration was also a highly significant predictor of peritoneal P removal that was has been reported earlier [17] and could be explained by an increased chemical gradient. This would also explain the highest peritoneal $\mathrm{P}$ removal in patients treated with CAPD+APD who at the same time had the highest plasma phosphorus values. This constellation indicates $\mathrm{P}$ retention in these patients despite higher removal. With regard to Na, CAPD+APD patients had the lowest values for overhydration measured with BCM (Fig. 2) that fit to the highest Na removal values. Therefore, it is important to analyse data on removal in combination with markers of retention such as overhydration or plasma P concentration to adequately assess solute homeostasis.

Weekly P removal on PD in our study was comparable to other studies $[9,13,17]$ : we achieved 8-12 mmol (248-372 $\mathrm{mg}$ ) per day corresponding to a weekly P dialysate clearance of $37 \mathrm{~L} /$ week in CAPD and $44 \mathrm{~L} /$ week in APD and CAPD+APD patients. These values are higher than that reported in a recent study comparing PD with HD [6]. The authors reported a weekly P dialysate clearance of only $33 \mathrm{~L} /$ week in a pooled sample of CAPD and APD patients that was significantly lower than in HD patients. This was driven by the extraordinary low clearance achieved with APD of $28 \mathrm{~L} /$ week whereas CAPD patients had a weekly clearance of $38 \mathrm{~L} /$ week. The reason for the low clearance on APD compared to our values must be related to the prescription. Unfortunately, that study did not report details on APD settings such as number of cycles, tidal volume or others or patient characteristics of the patients treated with APD. It mentions a high ultrafiltration suggesting a high number of cycles with short dwell times which is expected to result in lower P clearance. It is also conceivable that APD patients despite higher creatinine transporter status had low phosphorus transporter status and reduced phosphate transport $[9,13]$. With our data, we can convincingly show that $P$ removal is not necessarily inferior in APD patients and can be increased using CAPD+APD. Despite removal of 14-16 mmol P per day, dietary intake often exceeds this amount and was found to $20 \mathrm{mmol}$ per day or higher in a peritoneal dialysis patient [18]. To avoid P retention this difference must be absorbed by phosphate binders. Thus, determination of $\mathrm{P}$ removal helps to calculate the required dose of $\mathrm{P}$ binders which also has to take into account binding capacity of the used P binders and the dietary intake. 


\section{Kidney \\ Blood Pressure Research}

The limitations of this study are due to its retrospective and character, its single-center character and the low number of PD patients. PD modality was not controlled and subject to confounding by indication such as CAPD+APD in those with reduced residual function. Therefore, the groups had significant differences in their characteristics which we adjusted for using ANCOVA. We are aware that an interventional study with a crossover design would have been superior to study the efficacy of each modality as done by Demetriuo et al. [19], but our goal was to analyse the values obtained in a real-life setting. Therefore, we were able to follow the time dependence from begin of the monitoring. Values for both peritoneal and renal $\mathrm{Na}$ and $\mathrm{P}$ removal showed great intra- and interindividual variability which is commonly encountered in studies examining solute clearance in PD [20,21]. We addressed this by using a mixed model with time as independent variable and taking into account each replicate values of a patient.

\section{Conclusion}

Routine monitoring of $\mathrm{Na}$ and $\mathrm{P}$ removal increases awareness of maintaining $\mathrm{Na}$ and $\mathrm{P}$ balance in PD patients. Individualized adjustments of PD prescription including icodextrin use or higher glucose concentration can improve Na removal while P removal is mainly determined by the dialysate volume.

\section{Disclosure Statement}

The authors of this manuscript state that they do not have any conflict of interests and nothing to disclose.

\section{Acknowledgments}

We acknowledge the support by the Deutsche Forschungsgemeinschaft and the Open Access Publishing Fund of Tuebingen University.

\section{References}

1 Wanner C, Amann K, Shoji T: The heart and vascular system in dialysis. Lancet 2016;388:276-284.

$>2$ Artunc F, Nowak A, Muller C, Peter A, Heyne N, Haring HU, Friedrich B: Mortality prediction using modern peptide biomarkers in hemodialysis patients--a comparative analysis. Kidney Blood Press Res 2014;39:563-572.

3 Onofriescu M, Siriopol D, Voroneanu L, Hogas S, Nistor I, Apetrii M, Florea L, Veisa G, Mititiuc I, Kanbay M, Sascau R, Covic A: Overhydration, cardiac function and survival in hemodialysis patients. PloS One 2015;10:e0135691.

4 Stevens LA, Djurdjev 0, Cardew S, Cameron EC, Levin A: Calcium, phosphate, and parathyroid hormone levels in combination and as a function of dialysis duration predict mortality: Evidence for the complexity of the association between mineral metabolism and outcomes. J Am Soc Nephrol 2004;15:770-779.

5 Kuhlmann MK: Phosphate elimination in modalities of hemodialysis and peritoneal dialysis. Blood Purif 2010;29:137-144.

-6 Evenepoel P, Meijers BK, Bammens B, Viaene L, Claes K, Sprangers B, Naesens M, Hoekstra T, Schlieper G, Vanderschueren D, Kuypers D: Phosphorus metabolism in peritoneal dialysis- and haemodialysis-treated patients. Nephrol Dial Transplant 2016;31:1508-1514.

7 Bieber SD, Burkart J, Golper TA, Teitelbaum I, Mehrotra R: Comparative outcomes between continuous ambulatory and automated peritoneal dialysis: A narrative review. Am J Kidney Dis 2014;63:1027-1037. 


\section{Kidney \\ Blood Pressure Research}

Kidney Blood Press Res 2017;42:257-266

\begin{tabular}{l|l}
\hline DOI: $10.1159 / 000477422$ & (c) 2017 The Author(s). Published by S. Karger AG, Basel
\end{tabular}

Published online: May 19, 2017 www.karger.com $/ \mathrm{kbr}$

8 Rodriguez-Carmona A, Perez-Fontan M, Garca-Naveiro R, Villaverde P, Peteiro J: Compared time profiles of ultrafiltration, sodium removal, and renal function in incident capd and automated peritoneal dialysis patients. Am J Kidney Dis 2004;44:132-145.

-9 Courivaud C, Davenport A: Phosphate removal by peritoneal dialysis: The effect of transporter status and peritoneal dialysis prescription. Perit Dial Int 2016;36:85-93.

10 Devuyst O, Rippe B: Water transport across the peritoneal membrane. Kidney Int 2014;85:750-758.

-11 Fischbach M, Zaloszyc A, Schaefer B, Schmitt CP: Should sodium removal in peritoneal dialysis be estimated from the ultrafiltration volume? Pediatric Nephrol 2017;32:419-424.

-12 Cupisti A, Gallieni M, Rizzo MA, Caria S, Meola M, Bolasco P: Phosphate control in dialysis. Int J Nephrol Renovasc Dis 2013;6:193-205.

13 Bernardo AP, Contesse SA, Bajo MA, Rodrigues A, Del Peso G, Ossorio M, Cabrita A, Selgas R: Peritoneal membrane phosphate transport status: A cornerstone in phosphate handling in peritoneal dialysis. Clin J Am Soc Nephrol 2011;6:591-597.

$>14$ Botelho C, Rodrigues A, Oliveira JC, Cabrita A: Peritoneal phosphate removal varies by peritoneal dialysis regimen: An underestimated parameter of phosphate control. J Nephrol 2013;26:183-190.

-15 Blake P, Burkart JM, Churchill DN, Daugirdas J, Depner T, Hamburger RJ, Hull AR, Korbet SM, Moran J, Nolph KD: Recommended clinical practices for maximizing peritoneal dialysis clearances. Perit Dial 1996;16:448456.

16 Bissinger R, Artunc F, Qadri SM, Lang F: Reduced erythrocyte survival in uremic patients under hemodialysis or peritoneal dialysis. Kidney Blood Press Res 2016;41:966-977.

-17 Messa P, Gropuzzo M, Cleva M, Boscutti G, Mioni G, Cruciatti A, Mazzolini S, Malisan MR: Behaviour of phosphate removal with different dialysis schedules. Nephrol Dial Transplant 1998;13:S43-48.

-18 Jiang N, Fang W, Yang X, Zhang L, Yuan J, Lin A, Ni Z, Qian J: Dietary phosphorus intake and distribution in chinese peritoneal dialysis patients with and without hyperphosphatemia. Clin Exp Nephrol 2015;19:694700 .

19 Demetriou D, Habicht A, Schillinger M, Horl WH, Vychytil A: Adequacy of automated peritoneal dialysis with and without manual daytime exchange: A randomized controlled trial. Kidney Int 2006;70:1649-1655.

20 Steubl D, Roos M, Hettwer S, Angermann S, Wen M, Schmaderer C, Luppa P, Heemann U, Renders L: Comparison of peritoneal low-molecular-weight-protein-removal in ccpd and capd patients based on c-terminal agrin fragment clearance. Kidney Blood Press Res 2016;41:175-185.

-21 Liu Y, Cheng BC, Lee WC, Li LC, Lee CH, Chang WX, Chen JB: Serum potassium profile and associated factors in incident peritoneal dialysis patients. Kidney Blood Press Res 2016;41:545-551. 